http://dx.doi.org/10.5007/2175-7968.2013v1n31p119

\title{
JORGE AMADO AND THE INTERNATIONALIZATION OF BRAZILIAN LITERATURE
}

\author{
Elizabeth Lowe \\ University of Illinois at Urbana-Champaign \\ elowe@illinois.edu
}

\begin{abstract}
Jorge Amado (1912-2001) is the most translated Brazilian writer and the literary figure that has shaped the reception of Brazilian literature in the world. He is credited with opening the international literary market to the post-dictatorship generation of Brazilian writers. Yet Amado is also a controversial figure. The debate around him is sparked by what some believe is sexual and ethnic stereotyping in his post-1958 works and the reinforcement of "paternalistic "racial views. His reception therefore is mixed. For his English-language readers, he is a fascinating source of exotic and titillating narratives about the vast, unknown country of Brazil, and for Brazilians he is either a "great ambassador of Brazilian culture around the world" or a faux populist who disguises sexist and racist attitudes behind charming prose. This talk will address Amado's literary career, his unique contributions to Brazilian letters, the challenges of translating his work, and his influence on the production of a new Brazilian literature for export Keywords: reception, controversy, translation.
\end{abstract}

Jorge Amado is among the writers who have contributed most to the emergence of a post-modern Inter-American literature. He is at the same time a transitional and a controversial figure. Still the most widely translated Brazilian novelist-his works have appeared in over forty languages and in fifty-five countries-he was the 
first Brazilian writer to achieve commercial success in the United States. His work has been adapted to film, TV, and theatrical works and his novels have inspired the themes of Brazilian carnival samba schools. He is often compared to his famed contemporary, the Colombian Gabriel García Márquez in terms of the largeness of voice and vision in his works. His 1958 novel Gabriela, cravo e canela (tr. James L. Taylor and William L. Grossman, Gabriela, Clove and Cinnamon, 1962) was listed as one of the top twenty-five novels published in the United States in 1962 (Brower et al.,1). $\mathrm{He}$ is credited with opening the international market to the post-dictatorship generation of Brazilian writers. Until the recent renewal of interest in Clarice Lispector by the New York publisher, New Directions, Amado had the longest list of English-language translators, including James L. Taylor, William L. Grossman, Harriet de Onís, Helen Lane, Margaret Neves, Samuel Putnam and Gregory Rabassa. Barbara Shelby is responsible for at least six works, including his famous novella A Morte e a morte de Quincas Berro D'Água (1962; The Two Deaths of Quincas Wateryell, 1965) and his later novels Tenda dos Milagres (1969; Tent of Miracles, 1971), Tereza Batista Cansada de Guerra (1972; Tereza Batista: Home from the Wars, 1975), and Tietá do Agreste (1977; Tietá, the Goat Girl, 1979).

\section{Life and Letters}

Jorge Amado was born on a cacao plantation in what was then the tiny village named Ferradas, now a district of Itabuna in southern Bahia. He considered himself to be a citizen of Ilhéus, a city that was his childhood home and becomes a character in his novels and that shapes his characters' lives and world view. $\mathrm{He}$ attended high school in Salvador, the state capital and once the capital of Brazil until it was moved to Rio de Janeiro. He began his writing career as an adolescent and participated in the literary 
life of the city as a founder of the Modernist group called the "Rebels' Academy." He published his first novel in 1931, O País do Carnaval(Carnival Country), when he was 18 and his second novel Cacau (Cacao), came out two years later. His leftist political persuasion and activities prompted his first arrest in 1935 under the regime of Getúlio Vargas and his books were publicly burned. Although his books were banned in Portugal, France embraced him and his novel Jubiabá received ecstatic reviews in France, including from Nobel Prize winner Albert Camus. His communist militancy forced him into exile in Argentina and Uruguay in 1941. He returned to Brazil in 1945, separated from his first wife Matilde Garcia Rosa, and became a representative of the PCB, the Brazilian Communist Party. He was the architect of a law granting freedom of religion. At this time he also remarried, to the writer Zelia Gattai. Their son, João Jorge, was born in 1947, and in that same year his party was banned and its members arrested and persecuted. Amado chose exile for a second time, now in France where he stayed until he was asked to leave in 1950. From 1950 to 1952 he lived in Czechoslovakia, traveling often to the Soviet Union, where he won the Stalin Peace Prize in 1951.

Amado returned to Brazil in 1955 and this time he decided to put aside his political life and dedicate himself to writing. This period marks the beginning of what many critics call his second creative phase, initiated in 1958 with his novel Gabriela, cravo e canela, described by Jean-Paul Sartre as "the best example of a folk novel." Amado experienced a creative transformation, casting aside the social realism of his earlier works and producing the trilogy of novels with women heroines. His deceptively "realistic" portrayal of people, life and customs of Bahia and Ilhéus scandalized Brazilian society and for several years he could not set foot in Ilhéus because of threats from enraged citizens who believed that his characters were meant to represent them and that they had been libeled in the novels.

Amado was elected to the Brazilian Academy of Letters in 1961 and received the title of Doctor Honoris Causa from universities 
around the world. He was distinguished with the honorific title of Obá de Xangô of the Candomblé spiritist religion of Bahia. In 1987 the House of Jorge Amado Foundation was created in Salvador to promote the protection of his estate and the preservation of the culture of Bahia. He died on August 6, 2001.

\section{Amado and the Art of Character Development}

Amado's work is considered transitional because of the way his writings usher in a modern urban narrative through time-honored techniques derived from the Brazilian oral tradition. As Brower, Fitz and Martínez-Vidal observe:

One's opinion of Amado's skill as a novelist, in fact, can change rather dramatically if one considers works like Tent of Miracles, Home Is the Sailor, or The Two Deaths of Quincas Wateryell as not exemplifying the traditional realistic novel, but what we might think of as a new genre, the oral novel, or the oral tradition reconstituted in written novelistic form. Reading Tent of Miracles, for example, is very much akin to sitting in one's favorite bar listening to a master storyteller spinning out a great, sprawling yarn, replete with fascinating characters, endless subplots, and a constant commentary on the story-telling process itself, including the role of the listener/reader in it" (2).

In keeping with the orality of his narrative style, Amado painted portraits of people from the streets of Bahia that are so convincing as to seem "real" while at the same time investing them with symbolic content. He claimed to "release" characters from too-tight authorial control so that they could take on a life of their own. In fact, he claimed that he did not describe his characters; he let his readers imagine them. This is perhaps why the audiences of 
Amado adaptations in TV and film can so readily identify with the many portrayals of Gabriela, Dona Flor and Tereza Batista. Paulo Tavares has created taxonomy of over 4000 characters in Amado's narratives. Some are modeled specifically after historical figures and others are mythical. Amado "played" with people and history; while he described physical attributes, such as the calloused hands of plantation owners, he also focused with equal intensity on internal attributes. He represents a "way of being" as well as a "way of life." For this reason, the cities that provide the context of his works are treated like characters; characters and cities interact symbiotically.

Gabriela, Cravo e Canela is classified as a Brazilian novel that marks a transition between a modernist and "post-modernist" aesthetic, and is considered one of his best works. The action of the novel begins in 1925 in the provincial port of Ilhéus in Bahia. The city served as an important point for the distribution and export of cacao, the region's primary product and a topic of much discussion in the novel. The book tells two separate but related tales: first, the romance between Nacib Saad, a respectable bar owner of Syrian origin, and Gabriela, a beautiful young drought refugee from the impoverished interior, and second, the political struggle between the old guard of landed Cacao growers, led by the Bastos clan, and the forces of progress in the person of Mundinho Falcão, a wealthy paulista. It can be read simultaneously as an unusual, charming love story, a description of the political and social forces at work in 1920s Brazil, a somewhat satirical depiction of Brazil's aspirations to become a modern country, and a celebration of the local culture and pleasures of Bahia.

Dona Flor, after Gabriela, cravo e canela, is probably the best known of Amado's novels, some of its popularity having come from the success of the film version. The opening page summarizes the plot line: THE FEARSOME BATTLE BETWEEN SPIRIT AND MATTER . It tells the story of one Florípedes Paiva, a young, lower middle-class teacher of culinary arts in Salvador, Bahia, whose marriage 
to a promiscuous gambler, Vadinho Guimarães, is suddenly terminated by his premature death in carnival revelry. Despite his degenerate habits and constant exploitation of her, Flor is devastated, for the rogue was also her greatest source of pleasure and spiritual fulfillment with his zest for life and his taste for fine foods and uninhibited lovemaking. Though modest and shy by nature, she had defied both family and friends to marry him and, with his death, she feels that her life has ended. She tries to repress her sexual desires, which she considers unbecoming in a loyal, grieving widow. "Only a shameless woman, without love for her husband, could still think of such disgusting things-- how disgraceful!"she reasons with traditional self-abasement. Yet her erotic fantasies persist. The more she tries to dispel them, the stronger her neurosis becomes. Thus, although outwardly she appears to be content with her life of celibacy-- to be the 'perfect widow,' so to speak-- inwardly she is full of pent-up sexual frustration. She allows herself to be courted by the respectable and boring pharmacist, Teodoro, whom she weds conscious that this is a wiser choice of mate than Vadinho. But when the sexy Vadinho returns to her as a spirit, she succumbs to his charms again. Torn by guilt at betraying her new husband, she wavers and even initiates a candomblé spell to disappear him. At the last minute, she relents, and decides she must have both her husbands after all.

More than read, Amado was seen by his Brazilian audience. In fact, the media hoped to use his work in a national campaign for literacy and social integration at a time when the literacy rate in Brazil was very low. A lot of the work done by the media, including Rede Globo, was poor quality work for profit. The many adaptations of his women novels illustrate the ways in which his treatment of character opens the way to multiple interpretations. Dona Flor and Her Two Husbands, the movie (1978), directed by a then very young Bruno Barreto, was nominated for an Oscar as Best Foreign Film, and was the most successful Brazilian film of the era and an art house hit in the United States. The movie took Brazil by storm, 
grossing about $\$ 8$ million on a production budget of $\$ 600$, 000. It made leading lady Sonia Braga an exotic sex star for the better part of a decade. Its influence, particularly in interweaving culinary and carnal motifs, was evident in later imports such as Tampopo from Japan and Like Water for Chocolate from Mexico. Gabriela the movie (1983) also produced by Bruno Barreto and starring Sonia Braga and Marcelo Mastroianni, departs from the novel by suppressing two of its three parts: the racial identity of Gabriela and the focus on Ilhéus as a character (the subtitle of the novel is "crônica de uma cidade de interior" or chronicle of a provincial city). The novel examines the condition of women in Ilheusian society, a subaltern body at the mercy of a patriarchial social system. The film focuses exclusively on the sensual figure of Gabriela. While in the novel the Vesuvius bar is a meeting point for important people in the town where ideas and events are discussed, in the film the bar is limited to the place where Gabriela and Nacib have their sexual encounters. In Amado's novel, Gabriela has an important role as an agent of social and economic change; in the film she is reduced a sex object for a voyeur audience.

Dona Flor is an example of how Amado's techniques of character development contribute to her transformation from "uma pequena burguesa cheia de preconceitos" (a little bourgeoise full of petty ideas) into a character who offers "an alternative vision of gender, narrative voice and identity" (Payne and Fitz, 2). What at first limits and imprisons Flor (her gender, class and mixed race) is ultimately what liberates her. It enables her to see beyond a "stable and binary reality" to find stability in compromise. Flor decides not to choose between her living and her dead husband, and in so doing achieves balance and growth. Amado describes how he planned a very different ending for Flor. His version was that Flor would despair over giving herself back to Vadinho, and would "disappear" him under the candomblé spell she had initiated. Amado commented "Eu penso coisa assim meio poética, os dois desaparecendo, o outro marido entrando e vendo ela morte na cama." (I 
imagine something poetic, like the two of them disappearing, the other husband coming into the bedroom and finding her dead). Flor however, rebelled against her author and took authorial control by calling Vadinho back to her. Amado recounts:

\begin{abstract}
No dia seguinte, revi a cena e fui continuar. O que aconteceu então? Depois quer que o Vadinho fez amor com ela e foi embora, o marido entra no quarto, possui Dona Flor, e ela acha ótimo! Entao ela e nao eu, resolveu ficar com os dois. Eu nao esperava que Flor fosse capaz de romper com aqueles proconceitos todos...Dona Flor impôs o fim do livro. Toda vez que o personagem esta conduzindo o livro, você sabe que o livro está andando e toda vez que o personagem reage contra qualquer coisa, é você que está errado" (Hess and DaMatta, 44)

The next day, I looked at the scene again and continued. What happened then: After Vadinho makes love to her and leaves, the husband enters the room, possesses Dona Flor, and she thinks it's great! So she and not I decided to keep both of them. I did not expect that Flor was capable of breaking all of those taboos...Dona Flor decided the ending of the book. When a character takes over the book, you know it's going well and every time a character reacts against something, you, the author are wrong.
\end{abstract}

Amado works a great deal at Flor's character, relying on physical description and symbolic tropes, probes into her psychic life, and associates her character with a series of opposing emblems that characterize her social role. Amado poses the question: "Who is the real Dona Flor?" Her story is based on the formula of thesis, antithesis and synthesis. This Hegelian dialectic serves as the work's primary principle and the novel illustrates the need for a hybrid solution, one that will reconcile the best of two opposing forces while rejecting the worst (Chamberlain 1990, 63). Flor, like 
Ibsen's Hedda Gabler, realizes that an "either-or" solution is not an option. Ambivalence and sensuality are paired and endorsed as positive values. Aside from her prototypical role as an idealized Bahian woman, Flor can also be read as an allegory of the Getúlio Vargas dictatorship. Vadinho would be equated with traditional liberal populist politicians; Teodoro represents Marshal Humberto Castelo Branco and his hard-liner generals and technocrats; Flor is the icon of the Brazilian people. She is destined to "wage the terrible battle between matter and spirit" which the country must face if it is to achieve social equity and status as a modern nation. Each of Amado's heroines represents an aspect of Brazil's development as a post-colonial nation. Fundamental to Gabriela's nature is her freedom to pursue the sensual life-a statement of independence from the restraints of a nation colony in the grip of the colonizer and a metaphor of Brazil's lush natural bounty. Flor achieves personal satisfaction through independence of choice, and economic and political autonomy. Tereza Batista is a more stylized "legendary heroine" who does not experience the growth expected of a modern character. Hers is a parody of survival.

\section{Translating Amado}

The controversy around Amado is sparked by what some believe is sexual and ethnic stereotyping in his post-1958 works and the reinforcement of "paternalistic racial views" (Brower et al., 2). His reception, then, is very mixed. For his English and French language readers, he is a fascinating source of exotic and titillating narratives about the vast, unknown country of Brazil (a misreading) and for Brazilians, he is either a "great ambassador of Brazilian culture and civilization around the world" or a faux populist who thinly disguises sexist and racist attitudes behind charming prose. In this, Amado is akin to Darcy Ribeiro, the statesman, anthropologist and novelist, who has been accused of similar contradictions. 
Indeed, says Bobby Chamberlain, “Amado's signature tropes of "comical overstatement...sarcasm, class humor, playful anecdotes, and ribaldry" (2001, 32) not only set him up for misreading but also set the greatest challenges for the translator. "The novelist's propensity to caricature and his neo-romantic identification with the Brazilian masses are cited as proof of his literary naiveté. But his descacralization of canonical discourses and the perspicacity of his social satire frequently escape detection." (2001, 36-37). Joanna Courteau takes this as a step further to describe Amado's narrative process as an "engineering" of a "new national discourse in which tradition coexists with change, being displaced by it without violence" (48). How, then, is it possible to translate Amado's "utopian vision" or "malandro heaven" into the English language, which Lawrence Venuti, in his provocative book Scandals of Translation, insists is represented by publishers, professors and even translators as "the transparent vehicle of universal truth, thus encouraging a linguistic chauvinism, even a cultural nationalism" (cited in White, 242).

The difficulty in translating Amado with full justice lies both in language and point of view. The duality and personalism of Brazilian life, which Amado celebrates in his narratives, are difficult if not impossible to translate cross-culturally. Amado presents the "third, synthetic position" identified by Roberto da Matta, which is anchored in Brazilian institutions such as the jeitinho (getting around a rule or roadblock, usually through personal connections), and the Brazilian "relational or integrational ethic" (Chamberlain 2001, 38). The English-language reader can only interpret this as naïve and fanciful. For all the apparent simplicity of Amado's novels, he requires a sophisticated and culturally connected readership that can discern the ambiguity of his characters and plots. This cross-cultural paradox is artfully explicated in Catarina Edinger's essay titled "Dona Flor in Two Cultures." Edinger demonstrates how the 1982 film Kiss Me Good-bye turns Dona Flor into a situation comedy for a homogeneous American mass audience which 
completely misses the theme of choice and ambiguity that makes Flor an interesting character." The theme of choice and ambiguity is central to Dona Flor and consistent with the expression of Brazilian cultural and national identity that marks Amado and his generation. While the moral universe of the United States is, from the perspective of our neighbors in the Southern Hemisphere, "polarized," in Brazil, moral distinctions are not as clear. This subtlety is difficult to translate into the North American black-and-white ethical code.

\section{Amado the Humorist}

Amado's brand of folksy, off-color humor is very familiar to Brazilians but is another challenge to the translator. As is common knowledge, it is almost impossible to translate a joke and nothing is "more tedious than a joke explained" (Vincent, 253). Bobby Chamberlain categorized types of humor in Amado's work prior to 1975 but Jon Vincent believed there is "a sort of comic imperative at work in these novels-a kind of world view that defines scene, situation, and character in terms of an implicit opposite that makes the entire texture of the text comic" (253). Vincent explains that Amado's humor is directly connected to his political message. "While in some cases the intention may have an ethical or moral charge, his humor always functions at least on the margin of a political agenda of one kind or another" (253). While Amado clearly unleashes his inner joy in the later novels, Vincent observes that it is unlikely he only developed a sense of humor at the age of forty-six. He relates the story of Amado's joking side with the story of his attending an opera in China in 1952 with the Cuban poet Nicolas Guillénand his wife Rosa.

The Cuban interpreter had fallen asleep as soon as the opera began, so the monolingual Guillén and his wife had to 
rely on the retranslation provided by Amado through his French interpreter. The opera lasted for hours, and since it was staged without props or sets, was wide open to interpretation. The story, about the Emperor and his "Favorita" was changed by Amado from a medieval tale of derring-do to a pornographic extravaganza, with the Favorita being a nymphomaniac who has sex with men by the battalion and then has it with their horses. Days later the irate Guillén, in a meeting with Chinese Communist Party officials, rose to lambaste this monument to degeneration and poor taste, much to the bewilderment of the Chinese, until the imp in question made his confession by means of uncontrollable laughter (254).

Vincent traces a direct correlation between his "uncorking his imp's bottle" and his disillusionment with the PCB. When Gabriela was published in 1958 the critical response was "chaotic"-some accused him of becoming a "more subtle subversive" and others that he had just switched allegiance from Stalin to Krushchev. This public confusion itself was comical, and undoubtedly Amado thought so.

Vincent describes Amado's brand of humor as an example of Victor Raskin's script-based theory, in which the "opposition of overlapping scripts is the basic matrix for humor" (255). Amado liked to portray a situation from two perspectives, one from the first character and then from another of a different class. He shows how all the novels from Gabriela on are comic and that most have plots consisting of "overlapping scripts that makes the plots, in essence, jokes" (255). In Gabriela, the plot is structured around the different points of view of Gabriela and Nacib. The humor comes out of the contrast between his "squareness" and her "innocent hedonism." When he takes Gabriela back after annulling their marriage, he actually capitulates to her script. His friends comment that Nacib has become a "master of the good life" which glosses over the other script. This is funny to the reader, who is in on the 
"joke" that Nacib is a conventional man who doesn't understand Gabriela's motivations yet surrenders to her wishes; the characters who make these comments are not in the know. The operative motif in Gabriela is that she "subverts the natural order" (256). For Vincent, Dona Flor is Amado's funniest novel, and a good example of "double-scripting." Vadinho represents the povo (the people) and Teodoro the bourgeoise. The key sentence in the book is "Flor faz um sanduíche" (Flor makes a sandwich) which is a Brazilian slang term for ménage a trois. The novel is abundant in wordplay and caricature. Chamberlain notes it is also the "first novel to extensively exploit 'in-group humor'" (Vincent, 258). Amado often employed illustrators to help convey his complex message. In this case the first edition, illustrated by Floriano Teixeira, portrays caricatures of figures around the recently dead Vadinho, including the sculptor Mario Cravo, the artist Carybé, and Amado, plus an American tourist in a T- shirt with cameras who is the image of Alfred A. Knopf, Amado's American publisher at the time (258). Because Amado's fiction exploits "context in an invented space" it makes the work of the translator more challenging: the invented space has to be understood by the reader for the joke to work.

\section{A Singular Legacy: a poetics of diversity}

Jorge Amado, like Mário de Andrade and other writers before and after him, rejected the notion often expressed on the issue of race in Brazil that economic status and not race determines social status. Both writers insist that color is what determines acceptance or rejection into the social system. Moreover, they celebrate the mulatto as the dominant racial type of Brazil. In Tenda dos Milagres, there is a line that reads Dear "Colonel, what impresses you is the color and not the race...In Bahia, Colonel, it is hard to tell who is a mulatto." For these writers, just using race as a category of discrimination is too simplistic because hybridity and 
miscegenation are the bedrock of the Brazilian people and sexual unions between masters and slaves has been a reality since the days of colonization. Amado's books echo Gilberto Freyre's famous racial theories in arguing that Brazilian is the product of the mingling of color, race, and language. While Amado disagrees with some of Freyre's theories, he praised Freyre as a social revolutionary, insisting on the importance of Freyre in the process of democratization of Brazilian culture. Tannenbaum observes that "Freyre has given the Brazilian people a quiet pride in being what they are. As a single illustration Jorge Amado's Gabriela could not have been written before The Masters and the Slaves" (cited by Vieira, 234). Amado, according to Nelson Vieira, challenges the axiom of cultural homogeneity. Contrary to the idea of hybridity, that makes one of two distinct things, Amado's vision of mestiçagem is to celebrate diversity. Vieira says a homogenous ideology can occur when the State promotes the myth of racial democracy while irresponsibly neglecting the individual rights of its pluralistic citizenry. Amado consistently challenges the concept of cultural homogeneity. Amado uses the term racial democracy to defend miscegenation but at the same time his fiction points to the inhumanity of racism and intolerance by deconstructing issues of color, status and power. The glorification of the mulatta is such a deconstruction. The colonial practice of what Robert Young calls colonial desire, "a covert but insistent obsession with transgressive, interracial sex, hybridity and miscegenation," is played out in all of Amado's later novels, including Tenda dos Milagres (Vieira, 234). Vieira observes that Amado's fiction "repeatedly dramatizes Brazil's 'diversity' while simultaneously pointing to the 'different locations' of its people and the threat of losing their identity due to their unequal socio-economic-political status and the insidious color code which habitually draws upon authoritarian/hegemonic power to maintain the daily status quo" (236). Amado is consistent in advocating for racial miscegenation but he also consistently challenges the exclusion of the black from political and economic participation. Vieira 
points out how Amado builds his fictional arguments on the realities of race and culture in Brazil. Perhaps this explains why he can casually insert a comment that Gabriela was raped by a male relative as a "young girl" - while some have viewed this as a scandalously cavalier and gratuitous insertion, perhaps it can be seen as an example of Amado's "deconstruction of violent cultural production and hypocritical racial (and inter-gender) practices" (246).

\section{Understanding Jorge Amado}

Gregory Rabassa, in a well-known essay on translation, muses on the concept of "misunderstanding" that so often derails the reception of a foreign text in translation. He says that very often the misunderstanding does not come from a "wrong interpretation of the words involved, but rather than of what they stand for, an unawareness of the cultural barnacles that cling to them as they drift along cultural tides and eddies" (84). He talks about the differences between languages in lexical inventory that tie back to the concept systems and beliefs underlying different world views. Profane language has a special place in this inventory.

It may be that the societies that still must deal with horses and other living creatures have richer vocabularies than those of us who deal with dull machines. You can't berate a non-hearing Oldsmobile or Volkswagen with the same fervor that you can for a team of mules...I was distressed for my culture when I was translating Jorge Amado's Tocaia Grande (which came out as Showdown in English as the meaningful place name of the Portuguese was impossible to render in a cogent translation) and had to start repeating myself with words denoting the male member after the seventh or eighth time while Jorge went merrily through fifteen or sixteen versions, all in good, common usage in the state of Bahia. I will stick to translation in this case and leave interpretation to the anthropologists. (90-91) 
When asked if he was satisfied with the translations of his work, Amado replied

Translations are great when we can't read them...For me, the translations into Spanish, French or Italian are terrible because I can read them. For example, there's a translation into Spanish, which talks about 'jaca.' Jaca is a fruit... no, but in Spanish they didn't translate it as jack fruit. In Spanish they called it a "small sailboat." The could've at least called it a large sailboat, right? But the English translations...People tell me the translation of Gabriela is very well done. I know it was done with Professor Grossman's collaboration. He is a man of great authority, who knows Portuguese very well. Harriet de Onis, a woman who has now passed away, who was a professor at the University of Puerto Rico, translated other books of mine. I have the impression her translations must be good. I can't read English, but I have the impression they must be good because she put a lot of effort into them. She was very thorough, and did them with love, with great enthusiasm. An American woman, Barbara Shelby, a diplomat, translated other books of mine. She translated Tent of Miracles and Quincas Wateryell. Those who read the translation of Quincas and who know the text in Portuguese have told me the translation is very good. My brother James, who is a writer, who also translates very well into English, who has translated many American authors, such as Caldwell and others into Portuguese-read the translation of Tent and wrote to tell me it was very good. Obviously, there are things that are difficult to translate. For example, in Tent, there is something that marks the entire book, something we could say characterizes the protagonist from the beginning. It says he is "pardo, pobre e paisano" (racially mixed, poor and pacifist). Paisano is a popular way of saying one is against the military. However, she didn't translate "paisano" exactly in this way (she translated it as 'compatriot')...My brother found something very funny in this translation. In 
Bahia, in the language of Bahia, not of Brazil, we used the word "castelo" to refer to a brothel. So and so's Castelo, a castelo with many women, with many prostitutes. The main character, the protagonist in Tent of Miracles, lives his last years, his old age, in one of these castelos, one of these brothels. It's not as if he had become a prostitute; he just lived there. In one of the book's last scenes, after a very dramatic episode, he is walking along at the end of the afternoon toward the 'castelo' towards the brothel. But the translator just translated 'castelo' as 'castle'. And so the poor man, poor Pedro Arcanjo walks towards the brothel... and finds it very strange when he sees a castle in its place. These little things cannot be avoided. The most important content of the book remains: that which gives it life, blood, flesh, suffering, joy, the pain of being human. Anyway, I prefer the translations I cannot read" (Conversa III).

Here Amado does not mention another problem, with the translation of "tenda" which in Portuguese can mean shop, rather than tent. Rather than Tent of Miracles, the more accurate translation of the title might have been "Miracle Shop."

\section{A New Brazilian Literature for Export}

Jorge Amado, like Gabriel García Márquez and other writers of the Latin American Boom in the 1960s and 70s, opened up a new world to international readers. The success of his work and that of other writers of his generation is due to a combination of events. Some of this had to do with the moment. The Rockefeller Foundation sponsored the literary and marketing phenomenon of the Boom, and the rise of agents, editors, and translators who formed a close network to ensure the success of this literature. The Translation program at the Center for Inter-American Relations in New York and a translation subsidy program administered by the 
Association of American University Presses were established by Rockefeller philanthropies "to promote cross-cultural understanding... and furthering U.S. foreign policy interests" in the context of U.S. concern in the 1960s with the rise of Castro and the Cuban Revolution. Additionally, a few key publishers, agents, professional organizations, and literary journals supported this movement (Lowe and Fitz, xiii). Translators participated as architects of this phenomenon and often acted as agents for their authors and included Amado's translators. In addition to the translators, a cast of champions of Latin American literature in translation from the 1960 to 2000 includes publishing magnates such as Amado's publisher, Alfred A Knopf. Since 2000 the rate of publication of Latin American literature in translation has slowed. The current statistic is that a mere $3 \%$ of works of fiction published yearly in the US are works in translation, as compared to 27 per cent in France and 40 per cent in Brazil. An informal survey of well informed readers of international literature reveals that Jorge Amado does not currently have the same name recognition as other Latin American and Brazilian writers, such as Gabriel Garcia Marquez, Clarice Lispector or Machado de Assis. Martin Riker, an editor at Dalkey Archive Press, remarked that in his view, “Amado's name has not saturated the US literary culture the way names such as García Márquez or Cortázar has. In other words, his work has sold, but his name hasn't really come down as truly canonical in mainstream US literary culture" (email exchange, September 21, 2012). Eliot Weinberger, a translator of Octavio Paz, attributes the decrease in translations to multiculturalism which he says has led not to internationalism but a new form of nationalism. Instead of promoting foreign writers, the publishing industry promotes "hyphenated" American writers, foreign-born or of foreign parents. The chances of a Latin American writer being published in English today are very scant, yet translation into English is a coveted prize because it gains the author access to readership from other countries who can read the book in English. Even so, the writers and works 
discovered by cultural diplomats such as Barbara Shelby continue to fascinate, intrigue, and seduce. They represent an enigma, a cross-cultural puzzle and wonder. Amado is one of those writers. He has not only seduced readers of the English language, but also in the forty-nine other languages into which he has been translated. His popularity, due in part to his infectious brand of exoticism, has opened the way for other Brazilian writers to have their work translated in the United States and other countries. He set a standard for mass readership that publishers considered collateral to invest in other authors from his country. Amado also held appeal to former communist nations because of his lengthy association with leftist governments. A chameleon, he holds fascination for a diverse and geographically far flung readership because he appeals to basic human instincts.

In concluding these remarks, I cite Earl Fitz, who has written brilliantly about complex issues in understanding the phenomenon he calls Inter-American literature. In an essay comparing Jorge Amado and John Steinbeck, Fitz says that the basic point of comparison between these two Depression-Era writers is that they are "people's novelists, who at their best find their strength, truth and inspiration in the little people, the outcasts, the abused, and powerless, an approach to writing that had special poignancy for readers during the Great Depression of the 1930s. Speaking for these people, Jorge Amado and John Steinbeck became the consciences of their societies and, playing this vital role, they remind the rest of us, in visceral and sometimes crudely inelegant ways, that in our respective cultures not all is as it should be, that the "American Dream" like the "Brazilian Dream" is still a cruelly unattainable myth for some people"(121). Amado, like his Colombian counterpart, Gabriel García Márquez, created a myth of national identity and way of being Brazilian woven from the rich fabric of his imagination. The result is that Amado will continue to be loved and read because his works are a joy to read in spite of their artistic shortcomings and political incorrectness. To understand and appreciate 
Jorge Amado's universe we must read him in full context, the broad historical, social and spiritual environment of $20^{\text {th }}$ century Brazil, a country then and now in transition. This is our challenge as educators, translators and translation scholars, to open the way for future generations of readers to the discovery of worlds that intersect with our own. Our mission at the University of Illinois Center for Translation Studies is to educate future translators in the art and craft of translation, to turn our students into discerning readers and good writers, and to give them the tools and arguments to explain to fellow readers why reading international literature in translation is not only important but necessary. Jorge Amado and writers of his importance deserve to be read and re-read by new generations of readers around the globe.

\section{References}

Amado, Jorge. "Conversa III: Plantation Economy and the Planter Culture." Talk at Pennsylvania State University, October 21, 1971.

Chamberlain, Bobby J. Jorge Amado. Boston: Twayne, 1990.

Chamberlain, Bobby J. "Striking a Balance: Amado and the Critics." Brower, Fitz and Martinez Vidal, eds. Jorge Amado: New Critical Essays. New York \&London: Routledge, 2001. 31-41.

Courteau, Joanna. "Gabriela, Clove and Cinnamon: Rewriting the Discourse of the Native." Brower, Fitz and Martinez Vidal, eds. Jorge Amado: New Critical Essays. New York \&London: Routledge, 2001. 43-56. 
Fitz, Earl E. "The Vox Populi in the Novels of Jorge Amado and John Steinbeck." Brower, Fitz and Martinez Vidal, eds. Jorge Amado: New Critical Essays. New York \&London: Routledge, 2001. 111-121.

Edinger, Catarina. "Dona Flor in Two Cultures." Literature and Film Quarterly, v. 19, no. 4 (October 1991), pp. 235-241.

Hess, David J. and Roberto da Matta. The Brazilian People: Culture on the Borderlands of the Western World. New York: Columbia University Press, 1995.

Lowe, Elizabeth. "A Character in spite of her Author." Brower, Fitz and Martínez-Vidal, eds. Jorge Amado: New Critical Essays. New York and London: Routledge, 2001. pp. 125-131.

Lowe, Elizabeth and Earl E. Fitz. Translation and the Rise of Inter-American Literature. Gainesville: University Press of Florida, 2007.

Payne, Judith A. and Earl E. Fitz. Ambiguity and Gender in the New Novel of Brazil and Spanish America. Iowa City: University of Iowa Press, 1993.

Rabassa, Gregory. "Words Cannot Express...The Translation of Cultures.” Balderston and Schwartz, eds. Voice-overs: Translation and Latin American Literature. Albany: State University of New York Press, 2002. 81-94.

Riker, Martin. Email correspondence, September 21, 2012.

Tavares, Paulo. Criaturas de Jorge Amado. Rio de Janeiro: Editora Record, 1985.

Vieira, Nelson H. "Hybridity vs. Pluralism: Culture, Race and Aesthetics in Jorge Amado. Brower, Fitz and Martinez Vidal, eds. Jorge Amado: New Critical Essays. New York and London: Routledge, 2001. 231-251.

Vincent, Jon S. "The Imminent Imp: Humor in the Later Works of Jorge Amado." Brower, Fitz and Martinez Vidal, eds. Jorge Amado: New Critical Essays. New York and London: Routledge, 2001. 253-273. 
White, Stephen F. "Translation and Teaching: The Dangers of Representing Latin America for Students in the United States." In Balderston and Schwartz, eds. Voice overs: Translation and Latin American Literature. Albany: State University of New York Press, 2002. 235-244.

Recebido em 20/12/2012

Aceito em 04/03/2013 